\title{
Factors Are Affecting Tais Timor Consumers Purchase Decision in Alola Esperansa
}

\author{
Filomena da Costa ${ }^{1,}$ Luh Komang Chandra Dewi ${ }^{2}$, Augusto da Conceição \\ Soares $^{3}$ \\ Master's Program, Institute of Business (IOB), Timor-Leste ${ }^{1}$ \\ Faculty of Ecnomics and Business UNTRIM, Bali, Indonesia ${ }^{2}$ \\ Master'sProgram, Institute of Business (IOB), Timor-Leste ${ }^{3}$
}

\begin{abstract}
This study aims to analyze and explain: (1) To know and explain what factors influence consumer-purchasing decisions; (2) To find out and explain what factors are dominant in influencing consumer purchasing decisions; (3) to find out and explain what factors need to be improved in consumer purchasing decisions. The samples in this study were 80 of all customers or consumers of Alola Esperansa who had shopped Tais Timor at the Alola Esperansa Shop. Questionnaires were distributed to Alola Esperansa 80 consumers and all returned. The findings of this study indicate that the quality factor has the highest eigenvalue value of 5.218 and is able to explain the total variance of $32.612 \%$. The most dominant factor that consumers consider in buying Tais Timor at Alola Esperansa is the Quality Factor.
\end{abstract} Keywords: Quality Factor, consumer, purchasing decisions

\section{INTRODUCTION}

Purchsing decisions are a concept in purchasing behavior where consumers decide to act or do something and in this case make purchases or use certain products of services (Balawera, 2013). Consumer decision-making is a problem solving process. Researchers used this purchasing decision variable because the study of purchasing decisions is still feasible to be investigated considering that the increasing number of products in circulation result in the need for various considerations for the community in making purchasing decisions.

Producers must provide quality goods or quality as according to the Act of the República Decmocrática de Timor-Leste (RDTL) article 53 concerning (Consumer Rights) which read such as: Consumers are entitled to goods and services of good 
quality, to correct information and protection of health, safety and economic interests, as well as to obtain compensation for losess.

Most consumers usually interested in buying a local product that they want to carry to their home. The selling of which depends on the results of the local promotion and advertising which is carried out by sellers in accordance with the regulations or the Act of the República Democrática de Timor-Leste (RDTL) article 53 regarding (CONSUMERS RIGHTS) reads as follows. Advertising will be regulated by law, and any form of advertising that is hidden, indirect of contains elements of fraud is prohibited.

The following is data for goods provided by Alola Esperansa and the sales proceeds of Tais Timor as follows.

Table 1. Total Sales of Handicrafts in Alola Esperansa from 2016-2019

\begin{tabular}{|l|l|l|}
\hline \multicolumn{2}{|l|}{ Total Sales of Tais in 3 years } & Growth (\%) \\
\hline 2016 & $\$ 101,866.00$ & - \\
\hline 2017 & $\$ 96,372.00$ & $-6 \%$ \\
\hline & & \\
\hline 2018 & $\$ 144,124.00$ & $49,55 \%$ \\
\hline 2019 & $\$ 103,908.25$ & $-27,9 \%$ \\
\hline Average & $\$ \mathbf{1 1 1 , 5 6 7 . 5 6 2 . 5}$ & $\mathbf{5 , 2 \%}$ \\
\hline
\end{tabular}

Data Source: Alola Esperansa, 2019

Based on Tabel 1.1, it shows that sales growth Tais Timor experienced an average income increase of $\mathbf{\$ 1 1 1 , 5 6 7 . 5 6 2 . 5}$ or $\mathbf{5 . 2 \%}$ from 2016 to 2019, where the highest growth occurred in 2018 which increased by $\mathbf{\$ 1 4 4 , 1 2 4}$ or by $49.55 \%$. Meanwhile, the sales of Tais Timor experienced a decrease in income reaching $\mathbf{\$ 1 0 3 , 9 0 8 . 2 5}$ or $-27.9 \%$ occurred in 2019 and experienced a decrease in income in 2017, which reached $\$ 96,372$, or $-6 \%$. Therefore, it can be conclude that every year the amount of Alola Esperansa Ltd's income fluctuates.

One of the phenomena that has attracted the attention of the author is the phenomenon of circular of imitation products (counterfeit goods) as a new 
alternative in consumer consumption choices. Of course, you are familiar with the ASPAL (original but fake) trademark, which is a brand of various imitation products on the market. The methods are starting from marketing tricks, similarity in form, to branding plagiarism; do not hesitate to do so by these producers. This study adopts Hikmayanti Huwaida, Sri Imelda dan Rofi'I, (2016) Analysis of Factors That Affect Mobile Phone Purchase Decisions.

Based on the background of the problem, the author is interested in analyzing the factors that consumer purchasing decisions in purchasing Tais Timor at Alola Esperansa.

\section{Formulation of the problem}

From the above background, the formulation of the problem in this study is as follows:

1. What factors influence consumer-purchasing decisions?

2. What factors are dominant in influence consumer purchasing decisions?

3. What factors need to be improve in consumer purchasing decisions?

\section{Research Objective}

The objectives of this study are as follows:

1. To know and explain what factors influence consumer-purchasing decisions

2. To find out and explain what factors are dominant in influencing consumer purchasing decisions

3. To identify and explain what factors need to be improved consumer purchasing decisions

\section{RESEARCH METHODOLOGY}

This research uses descriptive research with a quantitative approach. Sugiyono (2015) said, "Descriptive research is aresearch conducted to determine the existence of independent variables, either only on one or more variables without making comparisons, or connecting with other variables (independent variables are independent variables, not independent variables, because the independent variable is always paired with the dependent variable)".

\section{Research Location}

The location of this research is Alols Esperansa, which is located in Mascarenhas Dili, Timor-Leste 


\section{Population}

The population of this study are people who become Alola Esperansa's consumers.

\section{Research Samples}

The sampling technique used in this study according to Supranto (2001), a good sample size can be determined by diverting the number of statement items in the questionnaire with numbers 5 to 10. In this study, the number of samples taken was 16 questions multiplied by 5 , namely 80 respondents. The researcher decided to take a sample of 80 respondents.

\section{Type of Data}

1. Quantitative data, namely data on sales of Tais in Dili

2. Qualitative data, namely using services provided by Tais Timor in Dili, Timor-Leste

\section{Data Source}

1. Primary data, namely in this study data obtained directly from respondents by distributing questionnaires

2. Secondary data, namely the researcher obtains data from Alola Esperansa and just uses it, for example data on the number of Tais sales in Dili.

\section{Data Collection Techniques and Procedures}

1. Interview

2. Documentation

3. Questionnaires

The tool used to measure is a Likert scale using a value range of 1 to 5 that scored as follows:

$\begin{array}{ll}\text { SA (Strongly Agree) } & =\text { Score } 5 \\ \text { A (Agree) } & =\text { Score } 4 \\ \text { N }(\text { Neutral }) & =\text { Score } 3 \\ \text { D }(\text { Disagree }) & =\text { Score } 2 \\ \text { SD } \text { (Strong Disagree) } & =\text { Score } 1\end{array}$


The operational definition of the variables in this stuty can be seen in Table 4.1 below:

\begin{tabular}{|c|c|c|}
\hline Variabel & Indicator & Statement item \\
\hline \multirow[t]{3}{*}{ Sosial } & \multirow[t]{2}{*}{ 1. Culture } & 1. Buy Tais Timor because it's trending \\
\hline & & 2. Using Tais Timor because of culture \\
\hline & 2. Social class & 3. Using Tais Timor because they feel proud \\
\hline \multirow[t]{2}{*}{ Kotler (2013) } & 3. Refence group & $\begin{array}{l}\text { 4. Using Tais Timor because of a recommendation from a } \\
\text { friend }\end{array}$ \\
\hline & 4. Family & $\begin{array}{l}\text { 5. Using Tais Timor because of a recommendation from } \\
\text { the family }\end{array}$ \\
\hline \multirow[t]{3}{*}{ Personal } & 1. Perception & 6. Information about Tais Timor is easy to get \\
\hline & 2. Learning & 7. Have experience using Tais Timor \\
\hline & 3. Motive & 8. Tais Timor has becaome a necessity \\
\hline \multirow{2}{*}{ Hawkins \& Mothersbaugh (2013) } & 4. Personality & 9. Beliving that Tais Timor is better than competitors \\
\hline & 5. Attitude & 10. Already accustomed to buy Tais Timor as a Souvenir \\
\hline \multirow[t]{2}{*}{ Marketing Mix } & 1. Products & 11. Buy Tais Timor because of its quality \\
\hline & 2. Prices & $\begin{array}{l}\text { 12. Prices are in accordance with the module, motive and } \\
\text { basic material }\end{array}$ \\
\hline \multirow{4}{*}{ Fandy Tjiptono (2013) } & & 13. Easy payment system \\
\hline & 3. Promotions & 14. Promotion of Tais Timor is very intense \\
\hline & 4. Distribution Channel & $\begin{array}{l}\text { 15. Tais Timor can be obtained in various places in Dili } \\
\text { (Tais Market, shop and airport) }\end{array}$ \\
\hline & 5. Physical Evidence & 16. Intresting with craft results \\
\hline
\end{tabular}

Source: Kotler (2013), Hawkins \& Mothersbaugh (2013), Fandy Tjiptono (2013) 


\section{Data Analysis Technique}

\section{Descriptive Analysis}

Descriptive analysis is use to analyze the collected data and is used to identify the characteristics of respondents, which include gender, age, occupation and income.

\section{Data Quality Test}

\section{Validity and Reliability Test}

1. The validity test aims to check whether the research question instrument is appropriate to measure what will be measure and can be understand by the respondent, which is indicate by the small percentage of respondents' answers that are too deviant from the average answers of other respondents. A Sugiyono (2001) "The minimum requirement to meet the validity requirements is if the item correlation is above $0.3(\mathrm{r}=0.3) "$. Thus, the question instrument whose item is less than 0.3 is declare invalid.

2. This reliability test aims to determine the extent to which the measurement results are reliable if measurements are carry out repeatedly. The reference used to determine the reliability of the research instrument based on the opinion of Arikunto (2002) is "An instrument is said to be reliable or reliable, if it has a reliability coefficient $(\alpha)$ of 0.06 or more".

\section{Factor Analysis}

1. The First Stage, Testing the Feasibility of Variables In this stage there are two things that need to be done so that the factor analysis can be carried out, namely the first according to Santoso (2013) by determining the value of KMO (Kaiser Meyer Olkin) Measure of Sampling Adequacy which is used to measure the adequacy of the sample with how to compare the partial coefficient with a minimum value of 0.5 .

2. Second, determining the value of Bartlett's Test of Sphericity, which is use to determine whether there, is a significant correlation between one variable and another. Furthermore, to see the correlation between independent variables can be consider in the Anti Image Matrices Table. The value considered is the value of the MSA Measure of Sampling Adequacy. The MSA value ranges from 0 to the following conditions: Santoso, (2013). 
MSA $=1$, the variable can be predicted without error by other variables.

a. MSA $>0.5$, the variable can still be predicte and can be analyse further.

b.MSA $<0.5$, the variable could not be predicted or could not be analyzed further, or excluded from other variables.

1. Second Stage, Determining the Number of Factors Determining the number of factors or factoring is the extraction process of a set of existing variables, so that one or more factors are form. The formed factor based on its eigenvalue.

The eigenvalue value is the sum of the variance values of the correlation of each factor against each variable that forms the factor in question. The greater the eigenvalue, the stronger the relationship between these factors to represent a group of variables. In Ghozali (2014), determining the number of factors is a combination of several correlated variables and based on the eigenvalue. If a variable has an eigenvalue $>1$, it is considered a factor, on the other hand, if a variable only has an eigenvalue $<1$, it is not included in the model.

2. Third Stage, Factor Rotation The next process is to do a rotation to clarify whether the factors formed are significantly different from other factors. At this stage, the factor matrix is transform into a simpler matrix, making it easy to interpret.

3. Fourth Stage, Naming the Factors the naming of each factor that has been form starts with the factor that has the largest eigenvalue to the smallest.

4. The fifth stage, the Model Accuracy Test is use to assess the accuracy of the model where there is a significant difference between the model and its observation value. The model accuracy test can be see from the amount of residual that occurs, what is mean by residual is the difference in observed, and produced correlation based on the estimation results of the factor matrix. Ghozali (2014). The smaller the residual percentage value, the more precise the technique is to determine. The model is said to be good if the coefficient that does not change or is the same is greater than $(>50 \%)$. 


\section{RESULTS AND DISCUSSION}

\section{Company history}

The Alola Foundation is a non-profit non-governmental organization operating in Timor-Leste to improve the lives of women and children. Founded in 2001 by Former First Lady Ms. Sword Kirsty Gusmão, an organization strives to foster women leaders and advocate for women's rights by addressing issues related to education, economic development, maternal and child health and advocating for women's rights.

\section{Analysis Results}

\section{Respondent Characteristics}

The number of respondents in this study were 80 consumers who had bought TaisTimor at Alola Esperansa. The presentation of data regarding the identity of the respondent aims to provide an overview of the respondent's condition. The description of the respondents who were the samples in this study, classified based on gender, age, occupation and opinion.

The following will discuss the categories of respondents.

Characteristics of respondents based on gender can be explain in Table 5.1 below:

\section{TABLE 5.1. CHARACTERISTICS OF RESPONDENTS BASED ON GENDER}

\begin{tabular}{lll}
\hline Gender & Frequency & Percent \% \\
\hline Man & 44 & 55.0 \\
Waman & 36 & 45.0 \\
\hline Total & 80 & 100 \\
\hline
\end{tabular}

\section{Source: Attachment 3}

Based on the data in Table 5.1, the number of respondents whom were consumers buying Tais Timor in Alola Esperansa who were male were 44 people or $55.0 \%$ and 36 people were female or $45.0 \%$.

Characteristics of respondents based on age can be explained in Table 5.2 below:

TABLE 5.2. CHARACTERISTICS OF RESPONDENTS BY AGE

\begin{tabular}{lll}
\hline Age & Frequency & Percent \% \\
\hline $17-25$ th & 13 & 16.3 \\
$26-30$ th & 17 & 21.3 \\
$>30$ th & 50 & 62.5 \\
\hline Total & 80 & 100 \\
\hline
\end{tabular}

\section{Source: Attachment 3}


Based on the data in Table 5.2, the number of respondents aged 17-25 years was the largest number of respondents, namely 13 people or $16.3 \%$, respondents aged 26-30 years were 17 people or $21.3 \%$, and respondents aged more than 3050 people or $62.5 \%$.

2. Characteristics of respondents by occupation can be seen in Table 5.3 below:

TABEL 5.3. CHARACTERISTICS OF RESPONDENTS BY EMPLOYMENT

\begin{tabular}{lll}
\hline Profession & Frequency & Percent \% \\
\hline Mahasiswa & 13 & 16.3 \\
Pegawai Negeri & 17 & 21.3 \\
Pegawai Swasta & 38 & 47.5 \\
Wiraswasta & 12 & 15.0 \\
\hline Total & 80 & 100 \\
\hline
\end{tabular}

\section{Source : Attachment 3}

Based on Table 5.3, it can be explained that the majority of respondents' jobs who bought Tais Timor at Alola Esperansa were as private employees, as many as 38 people or $47.5 \%$, as many as 13 students or $16.3 \%$ as civil servants as many as 17 people or $21.3 \%$, and as entrepreneurs and civil servants respectively as many as 12 peopleor $15.0 \%$.

Characteristics of respondents based on income can be see in Table 5.4 below:

TABLE 5.4. RESPONDENT CHARACTERISTICS BY INCOME

\begin{tabular}{lll}
\hline Profession & Frequency & Percent \% \\
\hline$>\$ 500.00$ & 23 & 28.0 \\
$\$ 115.00-\$ 250.00$ & 28 & 35.0 \\
$\$ 250.00-\$ 500.00$ & 19 & 23.8 \\
0 & 10 & 12.5 \\
\hline Total & 80 & 100 \\
\hline
\end{tabular}

\section{Source: Attachment 3}

Based on Table 5.4, it can be explained that the income of respondents who bought Tais Timor at Alola Esperansa was those who had an income above $\$ 500,000$, namely 23 people or $28.0 \%$, who had an income above $\$ 115.00$ - $\$ 250.00$, namely 28 people or $35.0 .0 \%$, which have an income above $\$ 250.00$ - $\$ 500.00$, which is 19 people or $23.8 \%$, while those who have an income of 0 or no job and still students are 10 people or $12.5 \%$,

\section{Validity and Reliability Test Results}

The validity test aims to check whether the research question instrument is appropriate to measure what will be measure and can be understand by the respondent, which is indicate by the small percentage of respondents' answers that are too deviant from the average answers of other 
respondents. According to Sugiyono (2001) "The minimum requirement to meet the validity requirements is if the item correlation is above $0.3(\mathrm{r}=0.3) "$. Thus, the question instrument whose item is less than 0.3 is declared invalid.Uji validitas dilakukan kepada responden dengan menggunakan analisis Corrected Item Total Correlation.

If the Corrected Item Total Correlation value for each instrument is positive, the amount is 0.3 , and above, then each item of the statement can be say to be valid.

According to Arikunto (2002), reliability testing aims to determine the extent to which the measurement results are reliable (reliable) when measurements are carried out repeatedly. The reference used to determine whether the research instrument is reliable or not is an instrument is say to be reliable or reliable, if it has a reliability coefficient $(\alpha)$ of 0.06 or more.

The test results are present in Table 5.5 with the help of SPSS software version 24.0 as follows:

TABEL 5.5. VALIDITY AND RELIABILITY TEST RESULTS RESEARCH INSTRUMENTS

\begin{tabular}{llll}
\hline Variable & $\begin{array}{l}\text { Corrected Item Total } \\
\text { Correlation (Validitas) }\end{array}$ & Descriptions & $\begin{array}{l}\text { Cronbach's } \\
\text { Alpha } \\
\text { (Reliabilitas) }\end{array}$ \\
\hline X1 & 0,521 & Valid & \\
X2 & 0,441 & Valid & \\
X3 & 0.534 & Valid & \\
X4 & 0,418 & Valid & \\
X5 & 0,420 & Valid & \\
X6 & 0,339 & Valid & \\
X7 & 0,623 & Valid & \\
X8 & 0,556 & Valid & \\
X9 & 0,445 & Valid & \\
X10 & 0,339 & Valid & \\
X11 & 0,402 & Valid & \\
X12 & 0,576 & Valid & \\
X13 & 0,540 & Valid & \\
X14 & 0,541 & Valid & \\
X15 & 0,496 & Valid & \\
X16 & 0,400 & Valid & \\
\hline
\end{tabular}

Source: Attachment 4 
Based on the data in Table 5.5, the variable has a Corrected Item Total Correlation value of less than 0.3 . Then the invalid variable will not be study further.

The reliability test that has been conducted shows that all statements are declare reliable because the value of the reliability coefficient is greater than 0.6 , namely 0.841 , and it can be said that the research instrument used is considered reliable.

\section{Factor Analysis}

In factor analysis, five steps must be carry out, including:

\section{Variable Feasibility Test}

According to Santoso (2013), in this stage there are two things that are necessary conducted so that factor analysis can be carry out, namely that first, by determining the value of KMO (Kaiser Meyer Olkin) Measure of Sampling Adequacy which is used to measure the adequacy of the sample by comparing the size of the partial coefficient with a minimum value of 0.5 . Second, determining the value of Bartlett's Test of Sphericity, which is use to determine whether there, is a significant correlation between one variable and another.

In Table 5.6 below, it can be see that the calculation results show the value of Bartlett's Test of Sphericity is 1512.808 at a significant 0.000 , which means that in this study there is a very significant correlation between variables and the results of KMO calculations show a value of 0.746 that means that the model can be say enough.

To determine whether the sampling process is adequate or not, the Measure Of Sampling Adequacy (MSA) measurement is used. In Table 5.6, it can also be see that all the variables that have been measure have an MSA value greater than 0.5 and no variables have an MSA value smaller than 0.5 , which means the variables can still be predicted and can be analyzed further to the next stage.

TABLE 5.6. VALUE OF KAISER MEYER OLKIN (KMO) MEASURE OF SAMPLING ADEQUACY, BARTLETT'S TEST OF SPHERICITY AND FEASIBILITY RESEARCH VARIABLES

\begin{tabular}{|c|c|c|c|c|}
\hline Variable & KMO & $\begin{array}{ll}\text { Bartlett } & \text { of } \\
\text { Sphericity } & \\
\end{array}$ & MSA & Descriptions \\
\hline $\mathrm{X} 1$ & \multirow{3}{*}{0,765} & & $0,858^{\mathrm{a}}$ & Worthy \\
\hline $\mathrm{X} 2$ & & & $0,754^{\mathrm{a}}$ & Worthy \\
\hline $\mathrm{X} 3$ & & & $0,766^{\mathrm{a}}$ & Worthy \\
\hline
\end{tabular}


ABM : International Journal of Administration, Business and Management, Vol. 2 No. 2 November 2020

\begin{tabular}{|c|c|c|c|}
\hline $\mathrm{X} 4$ & & $0,684^{\mathrm{a}}$ & Worthy \\
\hline $\mathrm{X} 5$ & & $0,633^{\mathrm{a}}$ & Worthy \\
\hline X6 & & $0,696^{\mathrm{a}}$ & Worthy \\
\hline X7 & & $0,740^{\mathrm{a}}$ & Worthy \\
\hline $\mathrm{X} 8$ & 492,620 & $0,790^{\mathrm{a}}$ & Worthy \\
\hline X9 & (Significant 0,000 ) & $0,770^{\mathrm{a}}$ & Worthy \\
\hline $\mathrm{X} 10$ & & $0,743^{\mathrm{a}}$ & Worthy \\
\hline $\mathrm{X} 11$ & & $0,708^{\mathrm{a}}$ & Worthy \\
\hline $\mathrm{X} 12$ & & $0,801^{\mathrm{a}}$ & Worthy \\
\hline $\mathrm{X} 13$ & & $0,852^{\mathrm{a}}$ & Worthy \\
\hline X14 & & $0,845^{\mathrm{a}}$ & Worthy \\
\hline X15 & & $0,786^{\mathrm{a}}$ & Worthy \\
\hline X16 & & $0,765^{\mathrm{a}}$ & Worthy \\
\hline
\end{tabular}

Source: Attachment 5

Determination of the Number of Factors 
After testing the feasibility of the variables, the next step is to determine the number of new factors that will be form. In Ghozali (2014) to determine the number of factors formed can be based on an eigenvalue value greater than 1 , if a variable has an eigenvalue value smaller than 1 then it will not be included in the model.

The results of the analysis of determining the number of factors are present in Table 5.7 below:

TABEL 5.7. DETERMINATION OF FACTORS

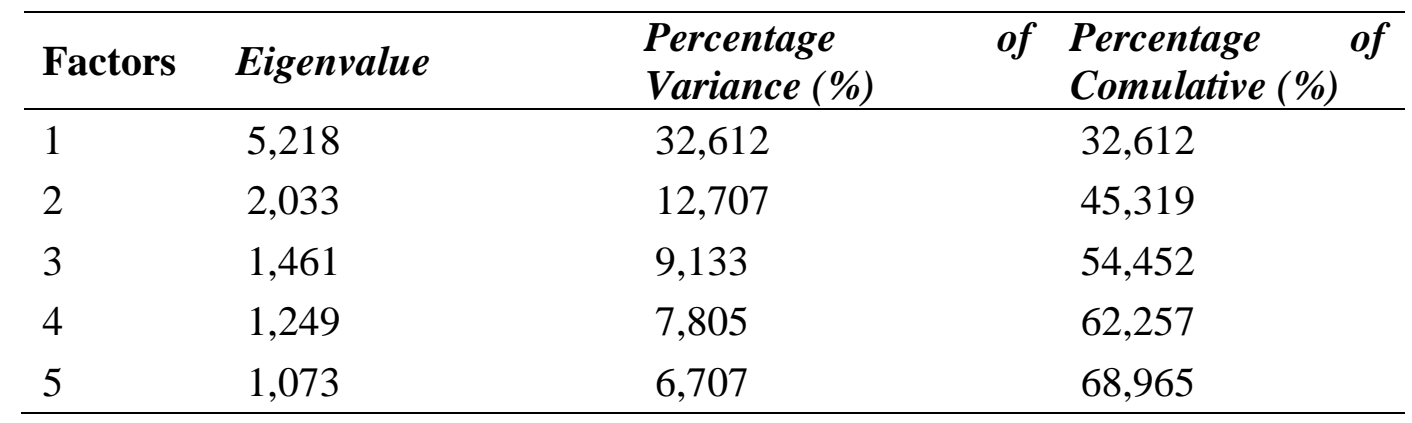

\section{Source: Attachment 6}

Based on Table 5.7, there are 5 factors that have an eigenvalue value greater than 1 . The first factor has an eigenvalue value of 5.218 with a variance contribution of $32.612 \%$. The second factor has an eigenvalue value of 2.033 with a variance contribution of $12.707 \%$. The third factor has an eigenvalue value of 1.461 with a variance contribution of $9.133 \%$. The fourth factor has an eigenvalue value of 1.249 with a variance contribution of $7.805 \%$. The fifth factor has an eigenvalue value of 1.073 with a variance contribution of $6.707 \%$. These five factors explain $68.965 \%$ of the total variants of consumer variables who buy Tais Timor at Alola Esperansa.

\section{Rotation Factor}

After knowing that there are five factors, which are the most optimal number, then in Table 5.8 below describes the Component Matrix, which shows the distribution to all statement items in this study on the five factors that have been form through factor rotation.

The process of determining which variables will go into which factor is carry out by comparing the magnitude of the correlation on each row in Table 4.8 below:

TABLE 5.8. DISTRIBUTION OF DIROTATED MATRIX COMPONENTS

\begin{tabular}{|c|c|c|c|c|c|}
\hline \multirow{2}{*}{ Variable } & \multicolumn{5}{|c|}{ Component } \\
\hline & 1 & 2 & 3 & 4 & 5 \\
\hline $\mathrm{X} 1$ &, 173 & ,099 & ,268 & ,009 & ,850* \\
\hline $\mathrm{X} 2$ & 055 & 180 &,- 051 & 321 & ,874* \\
\hline
\end{tabular}




\begin{tabular}{|c|c|c|c|c|c|}
\hline X3 & ,074 & ,103 & ,348 & ,895* &,- 083 \\
\hline $\mathrm{X} 4$ & ,066 & ,024 & ,414 &, $773^{*}$ & ,073 \\
\hline X5 & ,096 &, $767 *$ & ,411 &,- 016 &,- 121 \\
\hline X6 & 020 & ,784* & 149 & 120 & , 129 \\
\hline X7 &,- 038 &, $761 *$ & ,062 &,- 077 &,- 044 \\
\hline X8 & , 167 & ,801* & ,021 &,- 144 &,- 186 \\
\hline X9 & ,855* & ,433 & 093 & ,134 &,- 210 \\
\hline X10 & , 167 & ,226 &, $744 *$ & ,039 & ,352 \\
\hline X11 & ,248 & ,116 &, $834 *$ &,- 106 & ,614 \\
\hline X12 & ,735* & 102 & ,026 &,- 069 & ,074 \\
\hline X13 & ,809* & 013 & ,064 &,- 065 & ,002 \\
\hline X14 & ,768* & 061 &, 110 &,- 179 &,- 116 \\
\hline X15 &,- 142 &,- 076 &,- 043 & ,460 & 192 \\
\hline X16 &,- 236 & ,410 &,- 032 &,- 032 & 241 \\
\hline
\end{tabular}

\section{Source : Attachment 7}

Based on Table 5.8, it can be see that the value of each factor in the distribution process has met the requirements because the loading factor value of these factors is more than 0.5 . The loading factor value that has an asterisk (*) is the largest loading factor value per line. The first factor is form by the variables X9, X12, X13, X14. The second factor is composed of the variables X5, X6, $\mathrm{X} 7, \mathrm{X} 8$. The third factor is composed of the variables X10 and X11. The fourth factor is composed of the variables $\mathrm{X} 3$ and $\mathrm{X} 4$. The fifth factor is composed of the variables $\mathrm{X} 1$ and $\mathrm{X} 2$. Based on the results of the factor rotation, the next step will be to name the new factor.

\section{Naming Factors}

At this stage, the names of the factors that have been form are give based on the highest loading factor values. The names of these five factors can be see in Table 5.9 as follows.

TABLE 5.9. NEW NAMING FACTOR

\begin{tabular}{lllll}
\hline $\begin{array}{l}\text { Factor } \\
\text { Name }\end{array}$ & Variable Name & $\begin{array}{l}\text { Loading } \\
\text { Factor }\end{array}$ & Eigenvalue & $\begin{array}{l}\text { of } \\
\text { Variance }\end{array}$ \\
\hline Quality & $\begin{array}{l}\text { Prices are according to the } \\
\text { model, motif and basic } \\
\text { material (X12) }\end{array}$ & & & \\
& $\begin{array}{l}\text { Promotion of Tais Timor is } \\
\text { very intensively carried out }\end{array}$ & 0.717 & 5,218 & 32,612 \\
& (X14) & & \\
& Easy payment system (X13) & 0.710 & \\
\end{tabular}




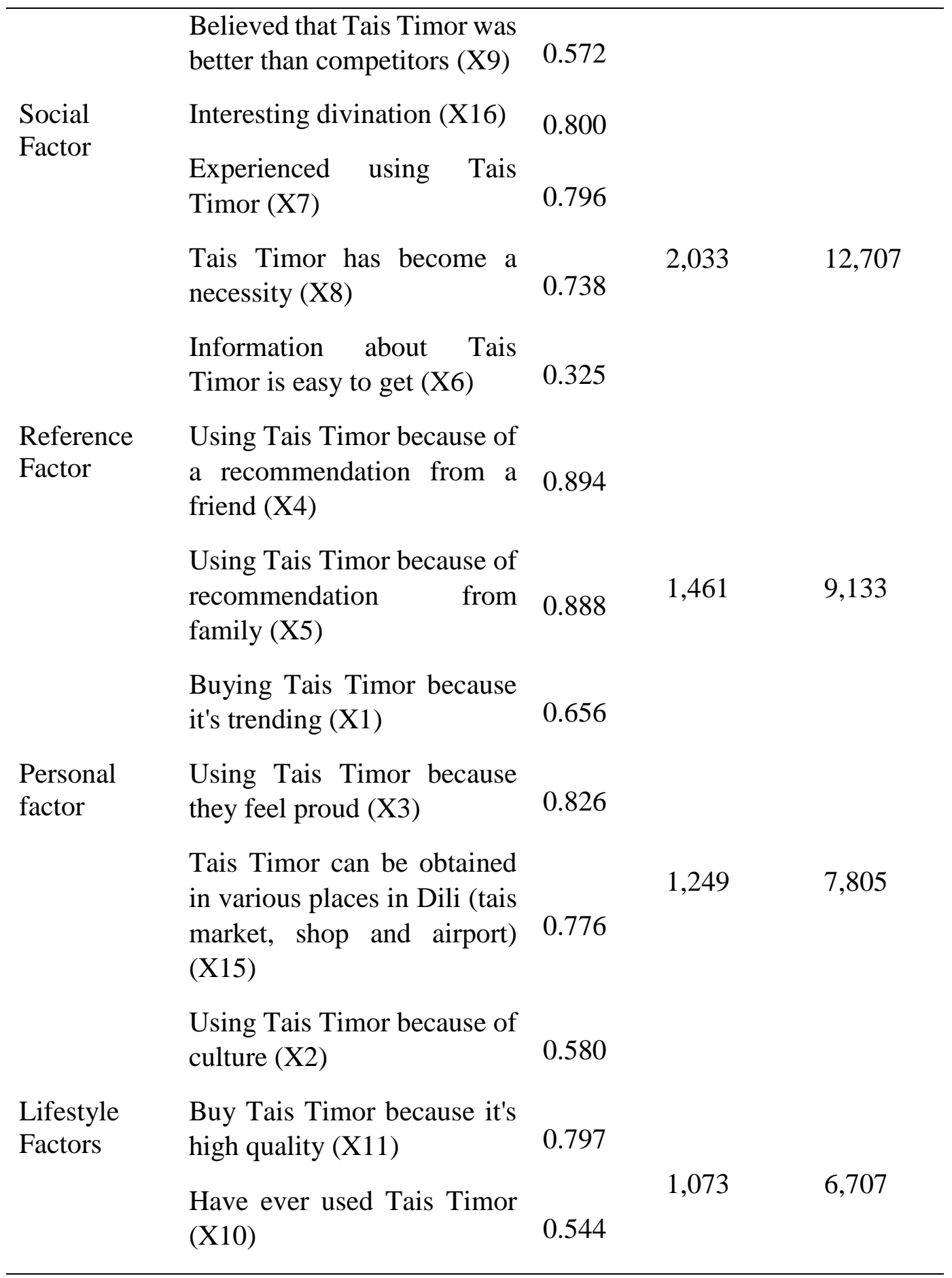




\section{Source: Attachment 6 \& 7}

Based on Table 5.9, the factor naming process produces five new factor names; the first factor is name Quality Factors because the constituents of these factors are indicators related to price and quality as well as better products than competitors. The second factor is named Social Factors because it is formed by very interesting results, many have used it, become necessities and are easy to obtain. The third factor is call the Reference Factor because in this factor it is compile by a variable regarding who uses Tais Timor in Alola Esperansa invitations from friends, family and trends. The fourth factor is name Personal Factors because it is compile by the pride and culture of the respondents. The fifth factor is name the Lifestyle Factor because this factor is form by the lifestyle of the respondent buying quality bags and is used to it.

\section{Module Accuracy Test}

This stage is the final stage in factor analysis, namely to determine the accuracy in choosing the analysis technique. In Ghozali (2014), the accuracy of the model can be see from the amount of residuals that occur, namely the difference in observed correlation with the correlation produced based on the estimation results of the factor matrix. The smaller the residual percentage value, the more precise the technique is to determine. The model is said to be good if the coefficient that does not change or is the same is greater than (> 50\%). By using SPSS version 24, it is known that the percentage of residuals is $0 \%$ or as much as 0 residuals with a significance of 0.00 . "This indicates that the model is acceptable with $100 \%$ model accuracy at a significance of 0.00 .

\section{Discussion of Research Results}

The factors that consumers consider in buying Tais Timor at Alola Esperansa are:

1. Quality Factor This factor has the highest eigenvalue value of 5.218 and is able to explain the total variance of $32.612 \%$. 
2. Social Factors This factor has a high eigenvalue value of 2.033 and is able to explain the total variance of $12.707 \%$.

3. Reference Factor This factor has an eigenvalue value of 1.461 and is able to explain the total variance of $9.133 \%$.

4. Personal factors. This factor has an eigenvalue of 1.249 and is able to explain the total variance of $7.805 \%$.

5. Lifestyle Factors This factor has an eigenvalue value of 1.073 and is able to explain the total variance of 6.707\%.Dominant Factor

The most dominant factor that consumers consider in buying Tais Timor at Alola Esperansa is the Quality Factor. This factor has the highest eigenvalue, which is 5,218 and is able to explain the total variance of $32,612 \%$. Based on the survey conducted and the results show that Alola Esperansa is promoting its products in the form of brochures and waiting for guests to come. For this reason, it is hoped that the promotion will be carry out using digital media in the form of social media in the form of Facebook, Instagram and participating in exhibitions held in Timor Leste.

\section{Research Implications}

Based on the discussion in this research, there are theoretical and practical implications regarding the factors that influence the consumer purchasing decisions of Tais Timor in the case study at Alola Esperansa.

\section{Theoretical Implications}

1. This research provides theoretical implications for the development of marketing management schience, in particular the theory of purchase decisions. In detail, the theoretical implications of this study contributes to the development of theories and concepts for the development of purchasing decisions, especially in the Tais Timor business.

2. The results of the research contribute to the development of previous research, especially findings regarding the factors that influence the purchase interest of a product, which includes excellence factors, marketing factors, social factors, references.

\section{Practical Implications}

This research also makes practical contributions to Alola Esperansa and other Tais businesses in Timor-Leste as follows: 
The results of statistical analysis show that consumer's buying interest in buying Tais Timor in particular or other products must pay attention to the decision-making process that is adjusted from the survey results with the importance of knwing the consumer's buying interest will be able to determine strategies in effective marketing activities to win market share.

\section{CONCLUSIONS}

Based on the two problem formulations, the results of the analysis and discussion that has been describe in the previous chapter, a conclusion can be draw as follows:

Five new factors were form that were consider by consumers buying Tais Timor at Alola Esperansa, namely as follows:

Quality factor, this factor has the highest eigenvalue value of $\$ 5.218$ and is able to explain the total variance of $32.612 \%$.

Dominant Factors, the most dominant factor. This factor has the Quality Factor. This factor has the highest engenvalue, which is 5,218 and is able to explain the total variance of $32,612 \%$.

\section{Suggestion}

The following are suggestions to complement the research results: Maintaining quality and adapting to today's practical lifestyles in payment is essentioal in order to remain competitive.

The most dominant factor that consumers consider in buying Tais Timor at Alola Esperansa is the Quality Factor, so it must be maintain and if nesassary improved.

\section{REFERENCES}

\section{(1) Book}

Arikunto, S. 2002. Metodologi Penelitian Suatu Pendekatan Proposal. Jakarta: PT. Rineka Cipta. Ghozali, 2014. Aplikasi analisis Multivariate dengan Program SPSS. Badan Penerbit UNDIP: Semarang.

Kotler dan keler, 2009. Manajemen Pemasaran. Jilid 1 Edisi Ke 13 Jakarta: Erlangga.

Kotler, P. 2013. Manajemen Pemasaran. Jilid II. Edisi Kesebelas. Alih Bahasa Benyamin Molan. Jakarta : Indeks

Sugiyono. 2001. Metode Penelitian. Bandung : Alfabeta.

Sugiyono. 2013. Metode Penelitian Kuantitatif, Kualitatif, Dan R\&D. Bandung: Alfabeta.

Sugiyono. 2015. Metode Penelitian Pendidikan. Bandung : Alfabeta. 
ABM : International Journal of Administration, Business and Management, Vol. 2 No. 2 November 2020

Supranto, J. 2001. Pengukuran Tingkat Kepuasan Pelanggan Untuk Menaikan Pangsa Pasar. Jilid I. Jakarta : Rineka Cipta.

\section{(2) Journal}

Balawera, A. 2013. Green Marketing dan Corporate Responsibility Pengaruhnya Terhadap Keputusan Pembelian Konsumen Melalui Minat Membeli Produk Organik di Freshmart Kota Manado. Jurnal EMBA, Volume 